\title{
Role of Green Tea on Lipid Profile of Normal and Hyperlipidemic Individuals
}

\author{
Tazeen Shah, Farheen Shaikh, Bibi Sarah, Khalida Sheikh, Shafaq Ansari
}

\begin{abstract}
OBJECTIVE: To evaluate the effects of green tea on serum lipid profile of healthy and hyperlipidemic individuals.

MATHADOLOGY: This case control, comparative study conducted in the Department of Physiology with the collaboration of Medical Research Centre, LUMHS Jamshoro from April 2015 to October 2015 after the approval from Ethical committee of LUMHS. Total sample size was 150 individuals, out of which 75 were healthy individuals as controls and 75 known hyperlipidemic subjects as cases. The sampling technique was random convenient sampling. Informed written consent was taken from all participants. Data was entered in Microsoft excel sheet and was analyzed on SPSS 16.0 (IBM, Incorporation, USA), Student t-test was applied for the analysis of variables. Statistical significance was defined as $p$-value of $\leq 0.05$.

RESULTS: Effects of green tea consumption after 3 months leads to observe the noticeable decrease in total cholesterol of hyperlipidemic subjects (from $260.9 \pm 26.13$ to $189.9 \pm 28.3 \mathrm{mg} / \mathrm{dl} \quad(p<0.05$ ), triacylglycerol (from $198.9 \pm 23.8$ to $130.8 \pm 14.5 \mathrm{mg} / \mathrm{dl}$ ) as compared with initial hyperlipidemic subjects $(p<0.05)$.Increase HDL-C levels of hyperlipidemic subjects after 90 days intake of green tea (from $28.93 \pm 4.86$ to $48.68 \pm 5.68 \mathrm{mg} / \mathrm{dl}$ and $p<0.05$ ) while $L D L-C$ in comparison to baseline, attenuating effects on hyperlipidemic individuals after intake of GT 90 days (from $166.6 \pm 10.2$ to $109.7 \pm 11.3 \mathrm{mg} / \mathrm{dl} \mathrm{p}<0.05$ ) as compared with initial baseline hyperlipidemic subjects. Serum VLDL levels also decreased in test group (from $42.17 \pm 5.65$ to $30.56 \pm 4.51 \mathrm{mg} / \mathrm{dl}$ ) with significant difference of $(p<0.05)$ as compared with the initial hyperlipidemic group.

CONCLUSION: Based on lipid lowering effect of green tea, and its capacity to reduce some of hyperlipidemia indices by significant amount. This study determines that the Green tea exerts beneficial effects on the cholesterol status of individuals.
\end{abstract}

KEY WORDS: Green tea, Lipid Profile, Hyperlipidemia

This article may be cited as: Shah T, Shaikh F, Sarah B, Sheikh K, Ansari S. Role of Green Tea on Lipid Profile of Normal and Hyperlipidemic Individuals. J Liaquat Uni Med Health Sci. 2018;17(04):225-9. doi: 10.22442/jlumhs. 181740582

\section{INTRODUCTION}

Hyperlipidemia is known to be the most hazardous factors contributing for the occurrence and severity of coronary heart disease (CHD). Hyperlipidemia signifies raised serum total cholesterol (TC), triacylglycerol (TAGs), low-density lipoprotein (LDL-C), and very low density lipoprotein (VLDL) with declined levels of high density lipoprotein $(\mathrm{HDL})^{1}$. This is a case control, comparative study. lipid disorders are considered to cause atherosclerotic cardiovascular diseases (CVD) ${ }^{2}$. Hyperlipidemia can be divided into primary and secondary types. Primary hyperlipidemia which may occur as a result of genetic anomalies and may be due to an unhealthy diet consumption and sedentary lifestyles ${ }^{22}$. Combined hyperlipidemia is known to be caused by simultaneous rise of TC and TAGs with HDL. Secondary hyperlipidemia may occur as a result of diabetes, excess alcohol consumption and adverse effects of drugs $^{3}$. Herbal remedies gained popularities since many years, due to significant attenuating effects on lipid profile by using of naturally occurring agents especially herbs and herbal extracts ${ }^{4}$. Traditional herbal remedies are raw mixtures which act synergistically to produce promising effects, that herbal medicine often considered to be less toxic than synthetic agents and so have given us way to the seek out new beneficial agents that have antioxidants, hypoglycemic and hyperlipidemic properties ${ }^{5}$.

Tea (Camellia sinensis) has been utilized as a beverage from ancient time second next to water. GT is rich in flavonoids ${ }^{6}$ and also rich in phytonutrients which are beneficial for health. Secrets of GT lays in its ample quantities of polyphenols - catechins, which exert powerful antioxidant activity ${ }^{7}$. A recent meta-analysis suggested that GT use might significantly decrease plasma total cholesterol andLDL-C. ${ }^{8} \mathrm{GT}$ catechins are strong stimulators to 
induce thermogenesis, hepatic $\beta$-oxidation, and hypolipidemic activity by lowering the intestinal absorption of lipids ${ }^{9}$. It is suggested by recent studies that stroke risks can be decreased by higher intake of green or black tea ${ }^{10}$. Human studies evidence on the fact that GT utilization can add up in minimizing the risk of atherosclerosis and cancer, it also activates the anti-hypertensive and antibacterial properties, body-weight control, and increases bone-mineral density ${ }^{11}$. There is evidence suggesting use of GT helps in the prevention and treatment of obesity and coexisting disease ${ }^{12}$ as the consumption of green tea is getting popular world wide due to its beneficial impact on an individual health ${ }^{13}$.

The aim of this study was to analyze the possible effects of daily intake of GT for twelve weeks on lipid profile of normal as well as hyperlipidemic patients.

\section{METHODOLOGY}

A case control, comparative design study was conducted at the Department of Physiology, in collaboration with the Medical Research Centre Liaquat University of Medical and Health Sciences Jamshoro. Total 150 males of the same age group were recruited and divided into two groups. Group A as controls, group B comprises of hyperlipidemic subjects as cases. Group-A comprised of 75 healthy individuals with normal general physical examination. Group-B comprised of 75 hyperlipidemic who were on diet control only and not taking any medications.

Inclusion criteria were both study groups include males of LUMHS office staff, who averagely consume 2 cups of tea usually hyperlipidemic subjects kept on diet control, with normal liver function test, nonsmokers, and non-alcoholics.

Exclusion criteria were the females excluded from the study. Patients who had any symptoms of infectious, tumor, immune diseases, possessing abnormal liver function tests, alcoholics and smokers, or even if they consume more than $200 \mathrm{mg}$ of coffee per day. Individuals who had any hyperlipidemic medicine or had undergone any other therapy during the last six months.

The experiment time was 90 days, hyperlipidemic individuals consumed Green tea at home twice a day. They were asked to avoid other drinks which containing caffeine during the experiment period.

Test Drink: Prepared an average cup of green tea from commercial products according to the instructions given on their wrapping. One pack contains $30 \mathrm{mg}$ caffeine and $83 \mathrm{mg}$ of catechins. Take $250 \mathrm{ml}$ of hot water for make GT (1.5 g tea bag, Lipton) standard single serving.

The data was collected before starting green tea and at the end of $3^{\text {rd }}$ month, taking general physical examination, including Pulse, blood pressure and lipid profile on proforma then filled the questionnaires.

Blood samples were taken at starting day of intervention and at end of $3^{\text {rd }}$ month, after overnight fast drawn $3 \mathrm{ml}$ of blood from each of the participant by venipuncture under ascetic measures then blood was centrifuged at $3000 \mathrm{rpm}$ for $10 \mathrm{~min}$. Serum was extracted and transferred it into Eppendorf cups then analyzing lipid profile on spectrophotometer (micro lab 300 Merck Corp., Germany) whereas kits for lipid profile were purchased from (Sigma; corporation)The lipid profile included, total cholesterol (TC), triacylglycerol (TAGs), high density lipoprotein (HDL-C), low density lipoprotein (LDL-C) and very low density lipoprotein (VLDL) respectively.

Present study was conducted under the strict ethical rules after the approval from Ethical Research Committee of LUMHS, Jamshoro.

Written informed consent was taken from all volunteers, who participated in the study and also explained the rational of the study.

The data was entered in Microsoft excel sheet and on the SPSS 16.0 (IBM, Incorporation, USA). The paired Quantitative data were respectively compared by student t-test.

\section{RESULTS}

The result of this study were expressed as mean \pm Standard deviation. Total 75 male as controls and 75 males hyperlipidemicas cases were selected in this study. Mean $\pm S . D$ age of controls and hyperlipidemic was noted as $45.54 \pm 3.4$ and $46.5 \pm 3.0$ years $(p<0.056)$ as shown in table I and represented in graph I.

Initial lipid profile: In comparison with initial serum levels of total cholesterol before intake of green tea were $149.5 \pm 30.4 \mathrm{mg} / \mathrm{dl}$ of controls and $260.9 \pm 26.13$ $\mathrm{mg} / \mathrm{dl}$ of cases, while TAG of cases group was $198.9 \pm 23.8 \mathrm{mg} / \mathrm{dl}$ as compared with control group $117.8 \pm 11.7 \mathrm{mg} / \mathrm{dl}$. HDL-C of hyperlipidemic individuals were $28.93 \pm 4.86 \mathrm{mg} / \mathrm{dl}$ as compared with control subjects $50.89 \pm 6.09 \mathrm{mg} / \mathrm{dl}$. Mean and SD of serum LDL of cases group was $166.6 \pm 10.2 \mathrm{mg} / \mathrm{dl}$ as compared with control group $75.34 \pm 11.8 \mathrm{mg} / \mathrm{dl}$ respectively. The serum VLDL levels of cases group was $42.17 \pm 5.65 \mathrm{mg} / \mathrm{dl}$ as compared with control subjects were $20.14 \pm 3.07 \mathrm{mg} / \mathrm{dl}$ and $(p<0.05)$ respectively as shown in table I and II whereas represented in graph I and II.

Green tea effects on lipid profile after 3 months: After 12 weeks of intervention, green tea 
supplementation lead to a significant decrease in serum lipid profile. In comparison with baseline, there was a significant decrease in serum total cholesterol from $(260.9 \pm 26.13$ to $189.9 \pm 28.3 \mathrm{mg} / \mathrm{dl})$ as compared hyperlipidemic subjects and the difference was statistically significant $(p<0.05)$ respectively as shown in table II and represented in graph 2.Serum TAGs levels of test group was reduced from $198.9 \pm 23.8$ to $130.8 \pm 14.5 \mathrm{mg} / \mathrm{dl}(\mathrm{p}<0.05)$ while serum HDL levels were increased to $48.68 \pm 5.68 \mathrm{mg} / \mathrm{dl}$ after 90 days of intervention as compared to initial baseline hyperlipidemic individuals $28.93 \pm 4.83 \mathrm{mg} / \mathrm{dl}$ therefore the difference was $(p<0.05)$ which is noted in table 2 and represented in graph II.

Serum LDL-C levels also declined in hyperlipidemic subjects after 90 days intervention from 166.6 \pm 10.2 $\mathrm{mg} / \mathrm{dl}$ to $109.7 \pm 11.3 \mathrm{mg} / \mathrm{dl}$ and found statistically significant $(p<0.05)$ respectively. Serum VLDL levels decreased in test group to $42.17 \pm 5.65 \mathrm{mg} / \mathrm{dl}$ from $30.56 \pm 4.51 \mathrm{mg} / \mathrm{dl}$ showed statistically significant differences as $(p<0.05)$ as shown in table II and graph II.

TABLE I: LIPID PROFILE IN CONTROL GROUP AND HYPERLIPIDEMIC SUBJECTS

\begin{tabular}{|c|c|c|c|}
\hline \multirow[t]{2}{*}{ Variables } & $\begin{array}{l}\text { Control } \\
\text { Group } \\
(n=75)\end{array}$ & $\begin{array}{c}\text { Cases Group } \\
\quad(n=75)\end{array}$ & \multirow[t]{2}{*}{ p-value } \\
\hline & \multicolumn{2}{|c|}{ Mean \pm SD } & \\
\hline Age (years) & $45.54 \pm 3.4$ & $46.5 \pm 3.0$ & 0.056 \\
\hline $\begin{array}{l}\text { Total cholesterol } \\
(\mathrm{mg} / \mathrm{dl})\end{array}$ & $149.5 \pm 30.4$ & $260.9 \pm 26.13$ & $<0.05$ \\
\hline TAGs (mg/dl) & $117.8 \pm 11.7$ & $198.9 \pm 23.8$ & $<0.05$ \\
\hline HDL-C (mg/dl) & $50.89 \pm 6.09$ & $28.93 \pm 4.86$ & $<0.05$ \\
\hline LDL-C (mg/dl) & $75.34 \pm 11.8$ & $166.6 \pm 10.2$ & $<0.05$ \\
\hline VLDL (mg/dl) & $20.14 \pm 3.07$ & $42.17 \pm 5.65$ & $<0.05$ \\
\hline
\end{tabular}

GRAPH I: INITIAL LIPID PROFILE OF CONTROL GROUP AND HYPERLIPIDEMIC SUBJECTS

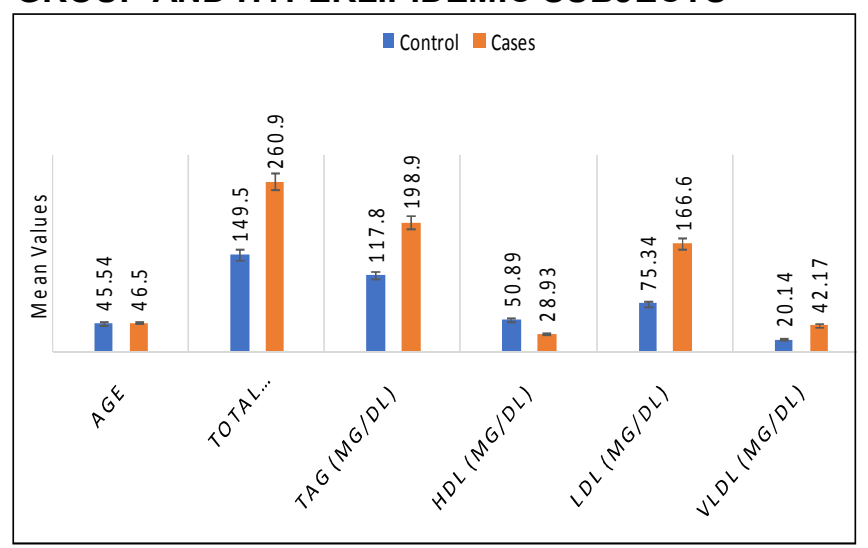

TABLE II:

EFFECTS OF GREEN TEA ON LIPID PROFILE OF HYPERLIPIDEMIC SUBJECTS AFTER 90 DAYS

\begin{tabular}{|l|c|c|c|}
\hline \multirow{2}{*}{ Variables } & Controls & $\begin{array}{c}\text { Cases } \\
\text { Subject after } \\
-90 \text { days }\end{array}$ & \multirow{2}{*}{ p-value } \\
\cline { 2 - 3 } & \multicolumn{2}{|c|}{ Mean \pm SD } & \\
\hline $\begin{array}{l}\text { Total cholesterol } \\
(\mathrm{mg} / \mathrm{dl})\end{array}$ & $149.5 \pm 30.4$ & $189.9 \pm 28.3$ & $<0.05$ \\
\hline TAG $(\mathrm{mg} / \mathrm{dl})$ & $117.8 \pm 11.7$ & $130.8 \pm 14.5$ & $<0.05$ \\
\hline HDL $(\mathrm{mg} / \mathrm{dl})$ & $50.89 \pm 6.09$ & $48.68 \pm 5.68$ & $<0.05$ \\
\hline LDL $(\mathrm{mg} / \mathrm{dl})$ & $75.34 \pm 11.8$ & $109.7 \pm 11.3$ & $<0.05$ \\
\hline VLDL $(\mathrm{mg} / \mathrm{dl})$ & $20.14 \pm 3.07$ & $30.56 \pm 4.51$ & $<0.05$ \\
\hline
\end{tabular}

GRAPH II: COMPARISON OF LIPID PROFILE BETWEEN CONTROLS, HYPERLIPIDEMIC SUBJECTS BEFORE AND AFTER GREEN TEA CONSUMPTION FOR 90 DAYS

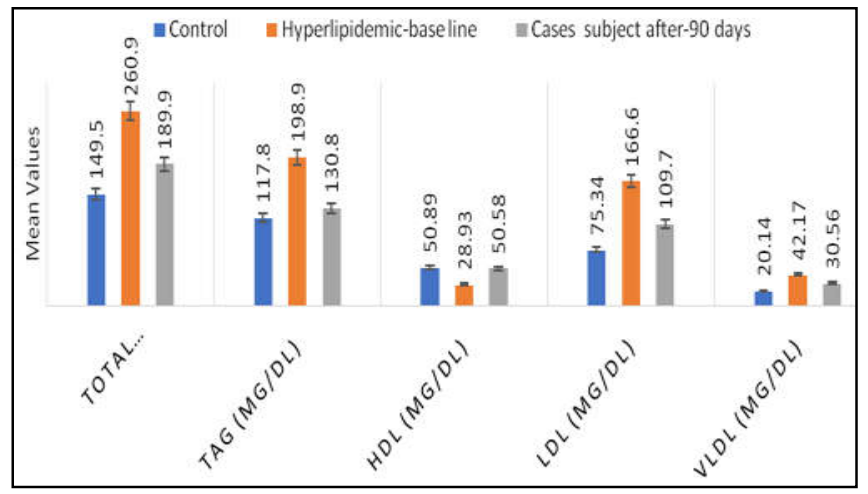

\section{DISCUSSION}

Green tea, Camellia sinensis is the common and richest source of polyphenols. Green tea have an antioxidant contents which remarkable capture the attention of researches to reduce the metabolic syndromes such as cardiovascular, hyperlipidemic and hyperglycemic effects ${ }^{14,23}$.

The present study was design to observe the green tea effects on lipid profile indices. There was a significant decrease in LDL-C from $166.6 \mathrm{mg} / \mathrm{dl}$ to $109.7 \mathrm{mg} / \mathrm{dl}$. Ghorbanzadeh B $2012^{7}$ had revealed in their study that the GT reduces plasma LDL-C and $\mathrm{TC}$, the findings of above in confirmation to present study.

Serum triglycerides levels were reduced with consumption of green tea, has been reported by a previous study ${ }^{15}$. GT reduced blood lipids in Zucker rats as has been cited ${ }^{16}$. In most recent study ${ }^{14}$, active young male were recruited for the placebo-controlled and double-blind design intervention study. This study reported a $24.9 \%$ increase in total fat oxidation 
and body fat was reduced significantly with GT but free fatty acid concentration remains unaltered ${ }^{17}$, these results complies with our results except free fatty acid, as the consumption of GT for 90 days markedly reduces serum TG from $198.9 \mathrm{mg} / \mathrm{dl}$ to $130.8 \mathrm{mg} / \mathrm{dl}$.

In animal study ${ }^{9}$ results shown after consumption of green tea the levels of total cholesterol, TAGs and LDL-C of the mice were significantly lower than those of the placebo group, while the level of HDL increased significantly. Study by Onakpoya I $2014^{5}$ reported a significant reduction in total cholesterol and LDL cholesterol. The findings of above study are highly consistent to our present study. Similar effects of GT, L-theanine (a constituent of GT) or caffeine had been reported by another previous study by Yoto $A 2012^{18}$. The intake of GT results in significant decreases in total cholesterol levels and LDL cholesterol, which strongly complies with the present study. ${ }^{19}$ An animal study GT supplementation given for 42 days, suggests that GT decreased TC, TAGs, LDL-C levels and increased HDL-C levels significantly ${ }^{20}$ which favors our results.

A previous study suggests consuming 6 grams of GT for 8 weeks is not effective in reducing blood lipid profile. The reason is because the values of TC, HDL-C, LDL-C and TAGs have no statistical difference ${ }^{21}$, these results are not consistent with our results may be the duration is not as long as used in this study.

\section{CONCLUSION}

Using GT for prolonged period decreases total cholesterol and LDL-C, increased level of HDL-C, which is beneficial for the prevention of hypercholesterolemia. The outcome extent on total cholesterol and LDL cholesterol appear moderate. Further research studies with a longer time and larger sample size are required to support our data.

\section{RECOMMENDATION}

There is paucity of data regarding the consumption of green tea in the society, emphasis should be given by the general practitioners for utilization of green tea in daily use, as it has many beneficial effects and the patients can benefit from its use, and the burden of lipid lowering drugs can be reduced by incorporating this herbal drink in routine life. An extensive research in required in this field to generate data to ascertain the beneficial effects of GT. In future we can anticipate scientific proves favoring present study.

\section{REFERENCES}

1. González Sandoval CE, Díaz Burke Y, Mendizabal-Ruiz AP, Medina Díaz E, Morales JA.
Prevalence of obesity and altered lipid profile in university students. Nutr Hosp. 2014; 29(2):31521. doi: 10.3305/nh.2014.29.2.7054.

2. Suliburska J, Bogdanski P, Szulinska M, Stepien M, Pupek-Musialik D, Jablecka A. Effects of green tea supplementation on elements, total antioxidants, lipids, and glucose values in the serum of obese patients. Biol Trace Elem Res. 2012; 149(3):315-22. doi: 10.1007/s12011-0129448-z.

3. Nelson RH. Hyperlipidemia as a risk factor for cardiovascular disease. Prim Care. 2013; 40 (1):195-211.

4. Zhang J, Wider B, Shang H, Li X, Ernst E. Quality of herbal medicines: Challenges and solutions. Complement Ther Med. 2012; 20(1-2): 100-6. doi: 10.1016/j.ctim.2011.09.004.

5. Onakpoya I, Spencer E, Heneghan C, Thompson $M$. The effect of green tea on blood pressure and lipid profile: A systematic review and meta-analysis of randomized clinical trials. Nutr Metab Cardiovasc Dis. 2014; 24(8):823-36. doi: 10.1016/j.numecd.2014.01.016.

6. Khalesi S, Sun J, Buys N, Jamshidi A, Nikbakht-Nasrabadi E, Khosravi-Boroujeni $H$. Green tea catechins and blood pressure: A systematic review and meta-analysis of randomised controlled trials. Eur J Nutr. 2014; 53 (6):1299-311. doi: 10.1007/s00394-014-0720-1.

7. Ghorbanzadeh B, Shahriari A, Tabatabaie R. Effect of Optional Consumption of Iranian Black and Green Tea on Lipid Profile of Serum and Liver in High-Fat Diet Rats. IJDO. 2012; 4(2): 79-85.

8. Peng X, Zhou R, Wang B, Yu X, Yang X, Liu K, et al. Effect of green tea consumption on blood pressure: A meta-analysis of 13 randomized controlled trials. Sci Rep. 2014; 4: 6251.

9. El-Sayed Mostafa U. Effect of Green Tea and Green Tea Rich with Catechin on Blood Glucose Levels, Serum Lipid Profile and Liver and Kidney Functions in Diabetic Rats. JJBS. 2014; 7(1):7-12.

10. Namal Senanayake SPJ. Green tea extract: Chemistry, antioxidant properties and food applications - A review. J Funct Foods. 2013; 5 (4):1529-41.

11. Manea AM, Vasile BS, Meghea A. Antioxidant and antimicrobial activities of green tea extract loaded into nanostructured lipid carriers. Comptes Rendus Chim. 2014; 17(4): 331-41.

12. Stendell-Hollis NR, Thomson CA, Thompson PA, Bea JW, Cussler EC, Hakim IA. Green tea improves metabolic biomarkers, not weight or body composition: A pilot study in overweight breast cancer survivors. J Hum Nutr Diet. 2010; 
23(6):590-600. doi: 10.1111/j.1365-277X.2010. 01078.x.

13. Lin SP, Li CY, Suzuki K, Chang CK, Chou KM, Fang $\mathrm{SH}$. Green tea consumption after intense taekwondo training enhances salivary defense factors and antibacterial capacity. PLoS One. 2014; 9(1): e87580. doi: 10.1371/ journal.pone.0087580.

14. Zheng XX, Xu YL, Li SH, Liu XX, Hui R, Huang $\mathrm{XH}$. Green tea intake lowers fasting serum total and LDL cholesterol in adults: A meta-analysis of 14 randomized controlled trials. Am J Clin Nutr. 2011; 94(2):601-10. doi: 10.3945/ajcn.110.010926.

15. Gahreman D, Wang R, Boutcher Y, Boutcher S. Green tea, intermittent sprinting exercise, and fat oxidation. Nutrients. 2015; 7(7):5646-63.

16. Yang $X R$, Wat $E$, Wang YP, Ko CH, Koon CM, Siu WS, et al. Effect of dietary cocoa tea (Camellia ptilophylla) supplementation on high-fat diet-induced obesity, hepatic steatosis, and hyperlipidemia in mice. Evidence-based Complement Alternat Med. 2013; 2013:783860. doi: 10.1155/2013/783860.

17. Roberts JD, Roberts MG, Tarpey MD, Weekes $\mathrm{JC}$, Thomas $\mathrm{CH}$. The effect of a decaffeinated green tea extract formula on fat oxidation, body composition and exercise performance. J Int Soc Sports Nutr. 2015; 12(1):1. doi: 10.1186/s12970014-0062-7.
18. Yoto A, Motoki M, Murao S, Yokogoshi H. Effects of L-theanine or caffeine intake on changes in blood pressure under physical and psychological stresses. J Physiol Anthropol. 2012; 31: 28. doi: 10.1186/1880-6805-31-28.

19. Snoussi C, Ducroc R, Hamdaoui MH, Dhaouadi K, Abaidi $\mathrm{H}$, Cluzeaud $\mathrm{F}$, et al. Green tea decoction improves glucose tolerance and reduces weight gain of rats fed normal and high-fat diet. J Nutr Biochem. 2014; 25(5):557-64. doi: 10.1016/j.jnutbio.2014.01.006.

20. Misaka S, Miyazaki N, Fukushima T, Yamada S, Kimura J. Effects of green tea extract and (-)epigallocatechin-3-gallate on pharmacokinetics of nadolol in rats. Phytomedicine. 2013; 20(14):1247 -50. doi: 10.1016/j.phymed.2013.07.003.

21. Lin X, Chen Z, Zhang Y, Luo W, Tang H, Deng B, et al. Comparative characterisation of green tea and black tea cream: Physicochemical and phytochemical nature. Food Chem. 2014; 173: 432-40. doi: 10.1016/j.foodchem.2014.10.048.

22. Memon AR, Shaikh F, Memon ZA, Abdul Majeed AB. Assessment of Lipid Profile \& Serum Total Protein in Patients with Hypertension. Ann Pak Inst Med Sci. 2017; 13(2):246-8.

23. Shah $T$, Shaikh F, Ansari $S$. To Determine the Effects of Green Tea on Blood Pressure of Healthy and Type 2 Diabetes Mellitus (DM) Individuals. Jlumhs. 2017; 04(16): 200-4. doi: 10.22442/jlumhs.171640533

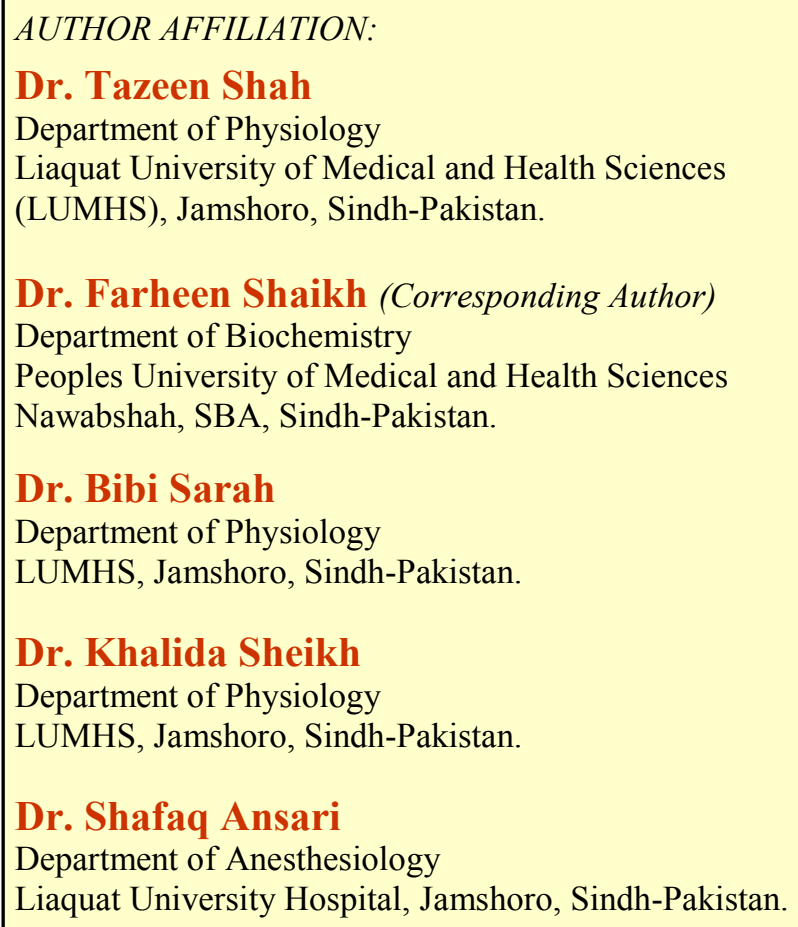

